\title{
粉末冶金用粉体の形状に基づく分級に関する技術開発と評価
}

\author{
伊藤 孝至, 鮕部 吉基 \\ 名古屋大学大学院工学研究科材料プロセス工学尃攻, $\overline{7} 464-8603$ 名古屋市千種区不老町.
}

\section{Particle Shape Classification Useful for P/M Powders}

\begin{abstract}
Takashi Itoh and Yoshimoto Wanibe
Department of Materials Processing Engineering, Graduate School of Engineering, Nagoya University, Furo-cho Cikusa-ku, Nagoya 464-8603.
\end{abstract}

Received June 21, 1999

\section{SYNOPSIS}

Particle shape classification technique of $\mathrm{P} / \mathrm{M}$ powders is introduced for high-grade powder preparation, which leads to the stabilization of $\mathrm{P} / \mathrm{M}$ processing and the high quality of $\mathrm{P} / \mathrm{M}$ products. The vibrating inclined plate method was used for the shape classification. In the particle shape separator, powder particles rolled down on an inclined plate vibrated by an electromagnetic vibrator. The morphological characteristics of both powders before and after testing were examined with the particle size-shape dispersion diagrams in order to investigate the influences of the operating conditions on the shape classification. Moreover, a simulation of this shape classification was attempted according to the kinetics of collision between ellipsoidal particles and an inclined plate.

\section{KEY WORDS}

particle shape classification, vibrating inclined plate method, powder morphology, particle size-shape dispersion diagram, powder property

\section{1 緒訔}

粉末治金プロセスにおいて,原材料である粉末の形態粒度 や粒子形状)に違いが生じることによって,製品の製造過程に 種々の問題を生じさせたり，製品の品質にばらつきをもたら したりすることがある.これらを解決するためには,粒度や形 状に基づいて分級した粉末を選択的に混合し，高度な粉末調製 を行うことが重要となる。しかし現状では，粒度による粉末 調製はできるものの, 粉末形状まで含んだ高度な調製はいま だ実現できておらず，これを目的とした研究も皆無である。

粉粒体の形状に主眼を置いた分級技術は，国内の資源りサ イクルの分野では一部研究が行われている1).しかし，より微 細な粉末を対象とする粉末治金の分野では，新たな基礎的知 見が要求される.そこで本研究では，微細粉末を含む粉末治 金用の粉末を対象にして，形状に基づく分級装置を自製して， 操作条件等の影響の検討や形状分級の計算機シミュレーショ ンの実施によって，粉末のための形状分級技術の確立と粉粒 体の高度調製のための基礎的知見の蓄積を目的とする.また， 分級㣪の粉末について，粒度一形状分散図による粉末形態特
性の評価や各種粉末特性の測定を実施し，形状分級の有効性 を確認する。

\section{2 形状分級，粉末の形態評価および粉末特性に関する 実験方法}

\section{1 形状分級装置}

粉末治金用粉末を形状に基づいて分級するための装置は自 製した. 分級方法は傾斜振動板によるものである.この装置 の概略図をFig.1に示す. 平板の傾斜方向に垂直でかつ水平面 と振動角をなす振動軸を持った電磁振動器を傾斜した平板に 取り付け，粉末粒子の排出孔(直径 $1 \mathrm{~mm}$ )をもったフィーダー ボックスを傾斜振動板上部端に，粉末の回収容器 14 個を傾斜 振動板の下部および側方にFig.1に示すように配置した. 個々 の粉末粒子は，振動によってフィーダーボックスの排出孔か ら徐々に排出し，傾斜振動板との衝突を繰り返しながら振動 によって側方に，重力場によって下方(傾斜方向)に転がりな がら移動し，Fig.1(b)に示すような軌跡をたどる．各粒子は， 最終的に板の端に配置した容器 $(\mathrm{A} \sim \mathrm{N})$ にて分離回収される. 
この分級原理は, 振動および重力場による衝突一転動の挙動 が粒子の形状の違いによって異なり変化することに基ついて いる。

\section{2 使用粉末と操作条件}

本研究では, 複雑形状の粒子から球形のものまで含む市販 の金属粉末(主にアルミニウム粉末)を試料に用いた.この分 級実験では，粒子同士の付着の影響を低減するために，粉末 試料を分級前に恒温槽 (約 $373 \mathrm{~K}$ )にて $2 \mathrm{hr}$ 以上乾燥させた。形 状分級の実態を明らかにするために，分級後に各容器で回収 した粉末の形態的特性と回収量を測定し，粉末の粒度，操作 条件(傾斜角，振動の振幅と周波数)および分級粉末の種類を 変化させて実施した形状分級の結果を比較検討した．なお， 本研究では振動角を $27^{\circ}$ に固定して実験を行った。

\section{3 粉末の形態的特性の評価}

粉末の形態的特性を測定するために，個々の粉末粒子の投 影像を光学顕微鏡とCCDカメラとを接続して画像解析装置に 取り込み，粒子の粒度(面積円相当直径) と形状 (円形度)の 測定を数千個の粒子について実施して，統計処理によって粒 度一形状分散図 ${ }^{2,3)}$ を得た. Fig.2(a)に粒子の粒度および形状の 定義と(b)に本研究で用いた市販のアトマイズアルミニウム粉 の粒度一形状分散図を一例として示す。

\section{4 分級粉末の粉末特性の測定}

粒度分級および形状分級の効果を調べるために，分級した

(a)

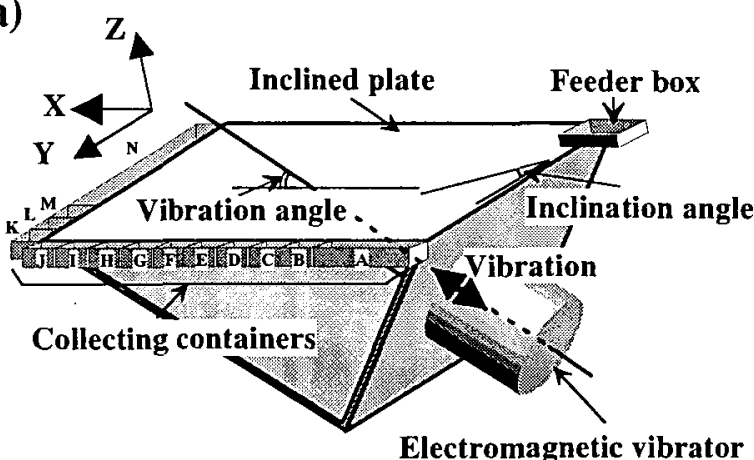

(b)

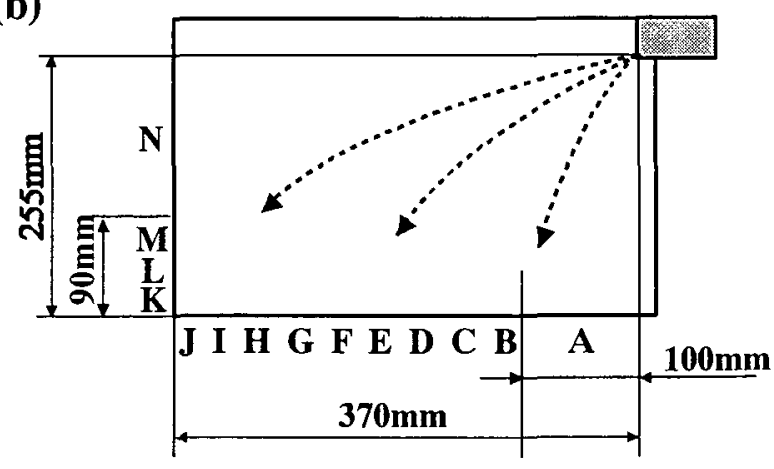

Fig.1 Schematic of a powder shape separator; (a) the outward and constructing parts of the apparatus and (b) the effective sizes of the inclined plate and the positions of the collecting containers.
粉末の粉末特性の測定を実施して, 市販アルミニウム粉末と それの粒度分級粉末および形状分級粉末の粉末特性值の比較 検討を行った．粉末特性として，安息角，流動度，充填密度 および圧粉挙動りの測定を実施した. 粉末特性の測定は, 粉末 試料を恒温槽 (約 $373 \mathrm{~K}$ ) にて $2 \mathrm{hr}$ 以上乾燥させた後に行った。 安息角は，Fig.3に示す排出法によって測定した。流動度は， JIS Z 2502に基ついてて規定された漏斗から粉末試料 $50 \mathrm{~g}$ が流出 に要する時間として測定した. 充填密度 (相対密度)は，粉末 の真密度に対する見掛密度の比として求めた。なお，見掛密 度はJIS Z 2504に基づいて測定した. 圧粉挙動は，直径 $15 \mathrm{~mm}$ の円柱形の金型にて粉末を一軸圧縮した際の荷重と変位量を 測定した。

\section{3 傾斜振動板法による形状分級の計算機}

$$
\text { シミュレーション }
$$

計算機シミュレーションでは，傾斜振動板との衝突を繰り

(a)
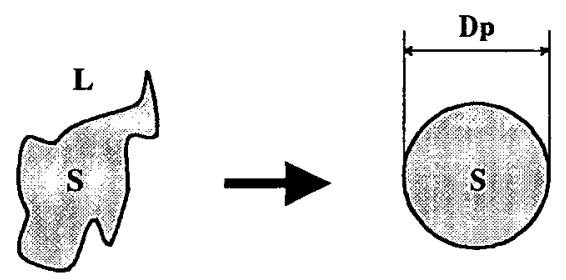

Projected image of particle : Circle of equivalent area(S) area(S) and perimeter $(L)$

$$
\begin{aligned}
& \text { Particle diameter: } D_{p}=(4 S / \pi)^{0.5} \\
& \text { Circularity : } \Psi_{c}=\pi D_{p} / L
\end{aligned}
$$

(b)

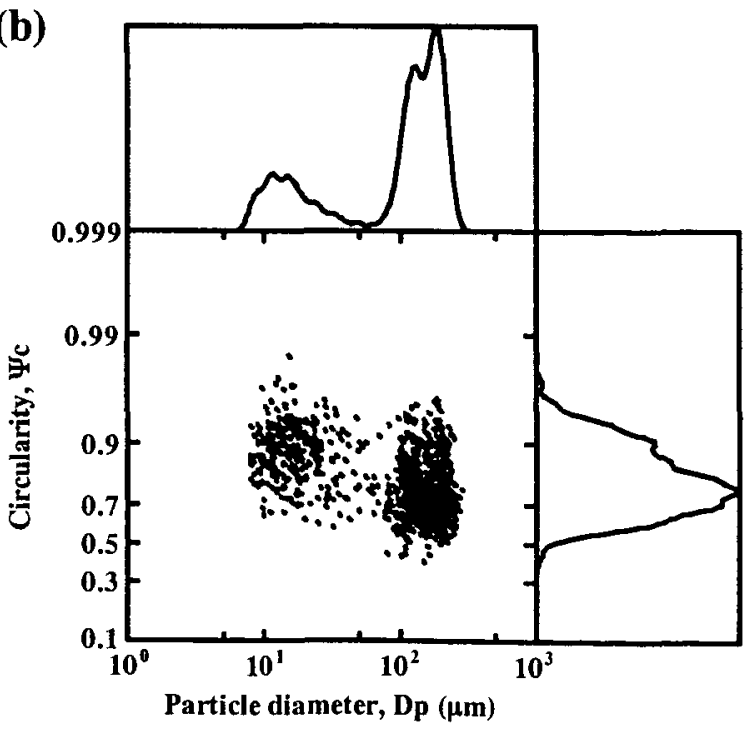

Fig.2 Definitions of particle morphology and a particle size-shape dispersion diagram; (a) the definitions of the particle size and shape and (b) the particle size-shape dispersion diagram of atomized aluminum powder as an example. 


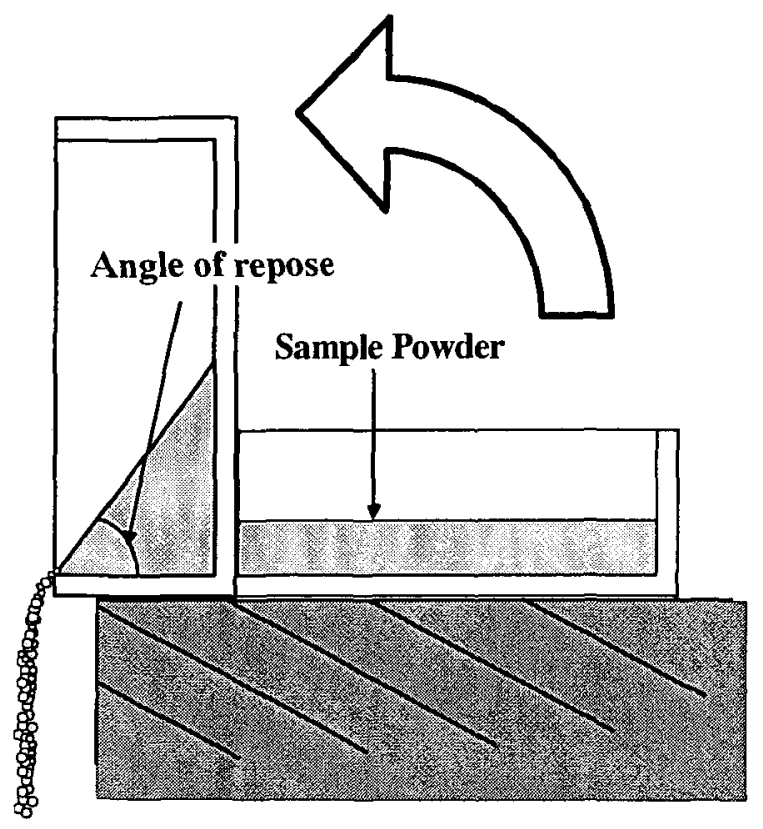

Fig.3 Schematic illustration of the apparatus and measurement for the angle of repose by the inclined method.

(a) as received (Inclination angle $=11.50 \mathrm{deg}$.)

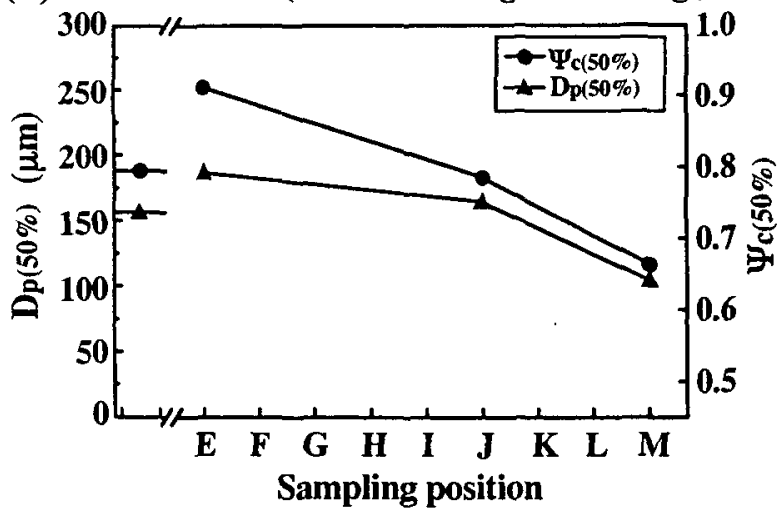

(c) $53-75 \mu \mathrm{m}$ sieved (Inclination angle $=15.83 \mathrm{deg}$.)

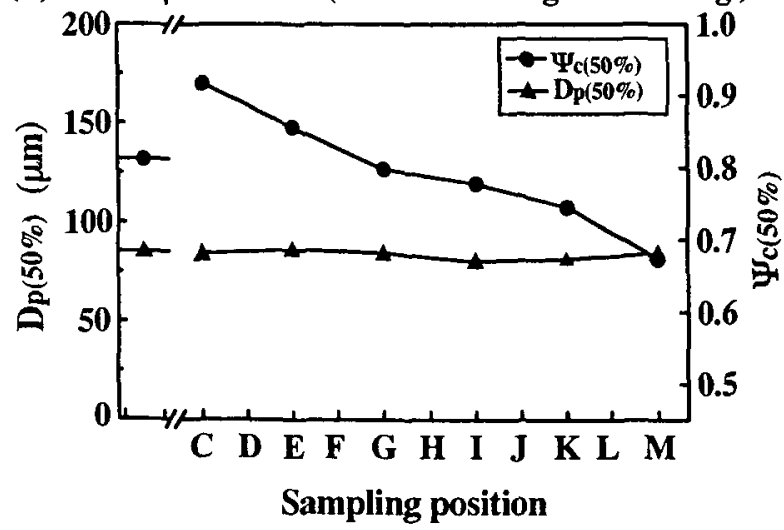

返しながら転動する粒子を, 長径, 中径, 短径を有する楕円 体形状とみなし, 傾斜振動板上を転動中は, 他の粒子との衝 突による転動挙動への干涉がないものと仮定した. 楕円体粒 子は，傾斜振動板と棈円体粒子との間で何度となく発生する 衝突の度に衙突後の速度および角速度を変化させるため, そ の都度運動量および角運動量に関する運動方程式を解き, 衝 突後の粒子の慣性モ一メント, 速度および角速度を求めた. 衝突後に傾斜振動板から離れた棈円体粒子は, 再度の衝突ま で重力場に従って空間を運動する。その間における慣性モ一 メントおよび角速度ベクトルは，衛突によって与えられた状 態を維持し変化しないものと仮定した. 以上のように, 衝突 と空間の運動を何回も繰り返し, 楕円体粒子が傾斜振動板の

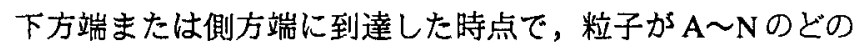
容器に入るかを調査し, 該当した容器の粒子個数をその都度 カウントするとともに，入った粒子の粒度と形状の情報を記 録した，なお，本シミュレーションでは，楕円体粒子と傾斜 振動板との闎の反発係数を 0.3 , 振動角を $27^{\circ}$, 振動の速度べ クトルとそれにって生じる撃力べクトルを関連づける式の比 例定数を0.6, 衝突時の楕円体粒子の弾性変形によるひずみ量 を $0.03 \%$ とした。

(b) $38-53 \mu \mathrm{m}$ sieved (Inclination angle $=20.00 \mathrm{deg}$.)

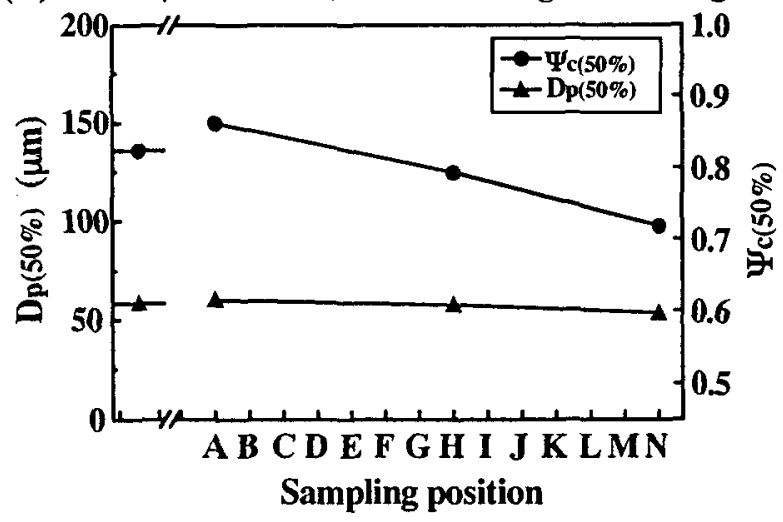

(d) $125-177 \mu \mathrm{m}$ sieved (Inclination angle $=10.17 \mathrm{deg}$.)

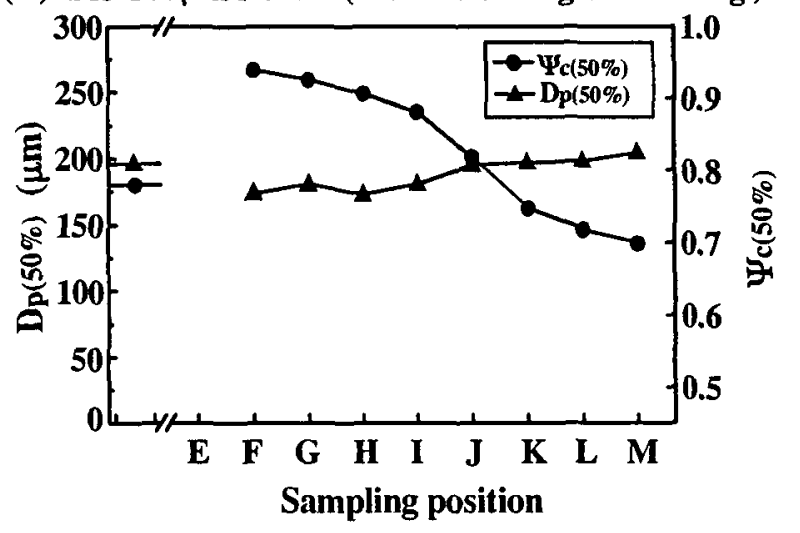

Fig.4 Average values of particle diameter and circularity of powders collected in each position after the shape classification under common conditions of amplitude $0.27 \mathrm{~mm}$ and frequency $40 \mathrm{~Hz}$; (a) as received powder, (b) $38-53 \mu \mathrm{m}$ sieved powder, (c) $53-75 \mu \mathrm{m}$ sieved powder and (d) $125-177 \mu \mathrm{m}$ sieved powder. 
4 実験およびシミュレーションによる形状分級結果 4.1 形状分級の実験結果

Fig.2(b)に示した粉末の形態特性を持つアトマイズアルミニ ウム粉に, 形状分級を試みた実験を傾斜角 $11.5^{\circ}$ ，片振幅 $0.27 \mathrm{~mm}$, 周波数 $40 \mathrm{~Hz}$ の操作条件で実施した. その分級結果 をFig.4(a)に示す.この図は, 分級後の各容器に回収された粉 末の平均円形度 $\Psi_{\mathrm{c}(50 \%)}$ および平均粒度 $D_{p(50 \%)}$ の変化を回収位 置に対してプロットしたものである.図の左端に示す数值は， 分級前の平均円形度および平均粒度である. 平均円形度は, フィーダーボックスから離れた位置ほど低い数值になってい ることがわかる。これは，即ち遠くの位置で回収された粉末 ほど複雑形状の粒子を多く含むことを意味し，形状による分 級効果が現れている.しかしながら，平均形状の数值も同様 の傾向があり，粒度による分級効果も連動して現れるため， 形状のみの分級が困難であることがわかる.

そこで，事前にふるいによって 3 水準に粒度分級したアト マイズアルミニウム粉を用いて形状分級を試みた。片振幅 $0.27 \mathrm{~mm}$ および周波数 $40 \mathrm{~Hz}$ の操作条件は固定として，粉末の 粒度に応じて傾斜角を変化させて実験を行った．その結果を

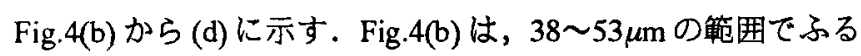
い分級した粉末を傾斜角 $20.0^{\circ}$ で形状分級した結果で，平均円 形度のみが回収位置によって大きく変化することがわかる． 同様に, Fig.4(c) および (d) は，ふるいの分級範囲がそれそれ 53〜 75 $\mu \mathrm{m}$ および 125 177 $\mu \mathrm{m}$ の粉末を，それそれ傾斜角 15.83および $10.17^{\circ}$ で形状分級した時の結果である. Fig.4(c) および(d)においても，平均円形度のみが回収位置によって大 きく変化することがわかる。これらの図は，事前の粒度分級 によって，粉末治金用粉体の実用粒度域での形状分級の可能 性を示唆している. 形状分級して得た粉末の投影像の例を Fig.5に示す.Fig.5(a),(b)および (c) は，それそれ Fig.4(d)に示 した形状分級で $\mathrm{G}, \mathrm{J}, \mathrm{M}$ の位置に回収された粉末粒子の投影像 である．回収位置による粒子形状の違いが明瞭に現れている ことがわかる.
4.2 実験とシミュレーションによる形状分級の比較

次に，形状分級の実験とシミュレーションと分級結果の比 較検討を行った.53〜75 $\mathrm{m}$ にふるい分級したアトマイスアル

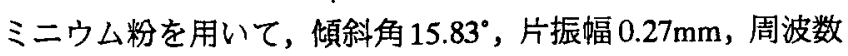
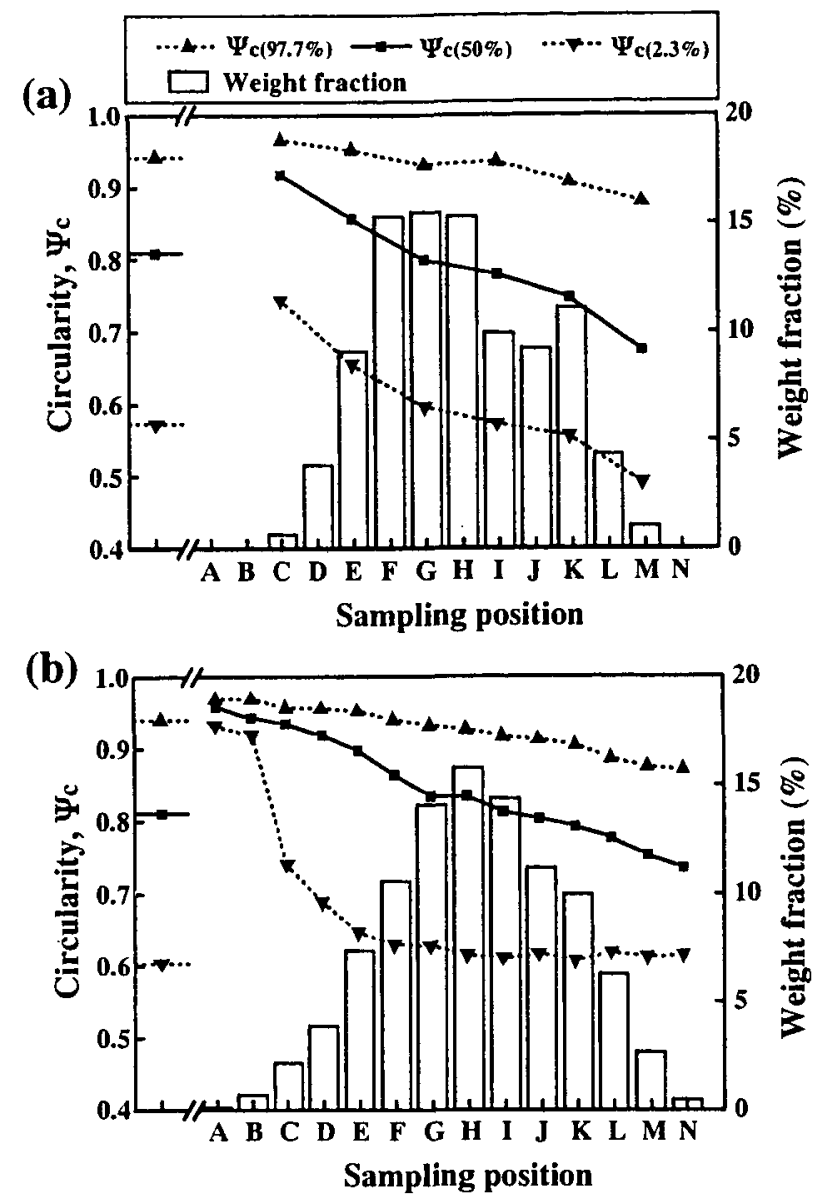

Fig.6 Comparison between the results of shape classification experimented and simulated under the same conditions of operation and powder; (a) the experimented and (b) the simulated. (a) Sampling position $\mathbf{G}$

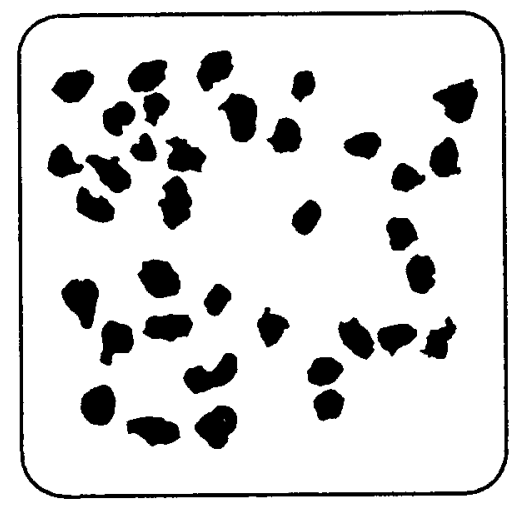

(b) Sampling position $\mathbf{J}$

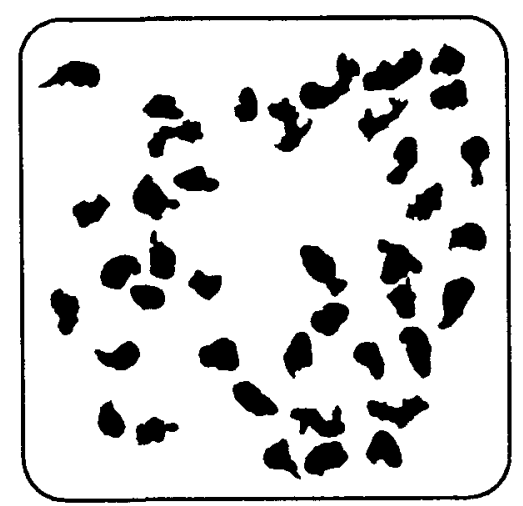

(c) Sampling position $\mathrm{M}$

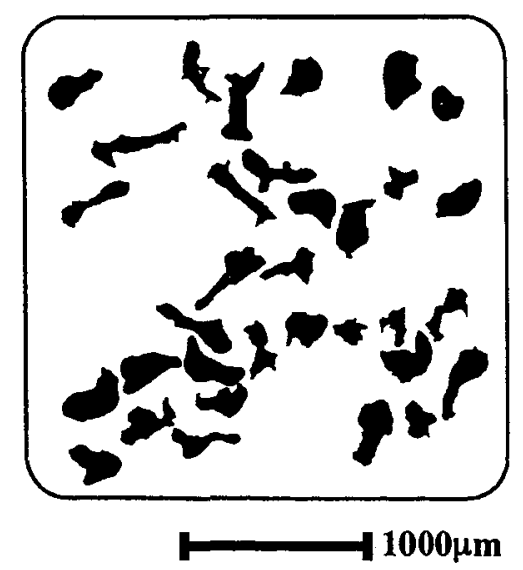

Fig.5 Three types of projected images of powders classified on particle shape collected in (a) position G, (b) position J and (c) position M. 
$40 \mathrm{~Hz}$ の操作条件で形状分級を実施した。計算機シミュレー ションにおいても，同じ条件の粉末の粒度一形状分散図の データに基づき，同じ操作条件で実施した.それぞれの形状 分級結果を Fig.6(a)と(b)に示す. Fig.6(a)では，形状分級の実 験で得られた平均円形度 $\Psi_{c(50 \%)}$, 積算円形度分布で $97.7 \%$ お よび $2.3 \%$ に相当する円形度 $\Psi_{c(97.7 \%)}$ と $\Psi_{c(23 \%)}$ の回収位置にお ける変化を折れ線グラフで，回収割合を榛グラフで示す．円 形度 $\Psi_{c(97.7 \%)}$ と $\Psi_{c(23 \%)}$ は，円形度分布の分布範囲の指標として 用いている. 回収位置によって，平均円形度とともに円形度 分布の幅も変化し，位置が遠いほどその幅は搪大しているこ とがわかる.Fig.6(b) は, シミュレーションによる同様な形状 分級結果である。この操作条件において，平均円形度の回收 位置による变化は，実駼結果に比較的よく一致している。 円 形度分布の幅は，実験結果に比べ広くなる傾向があるが，回

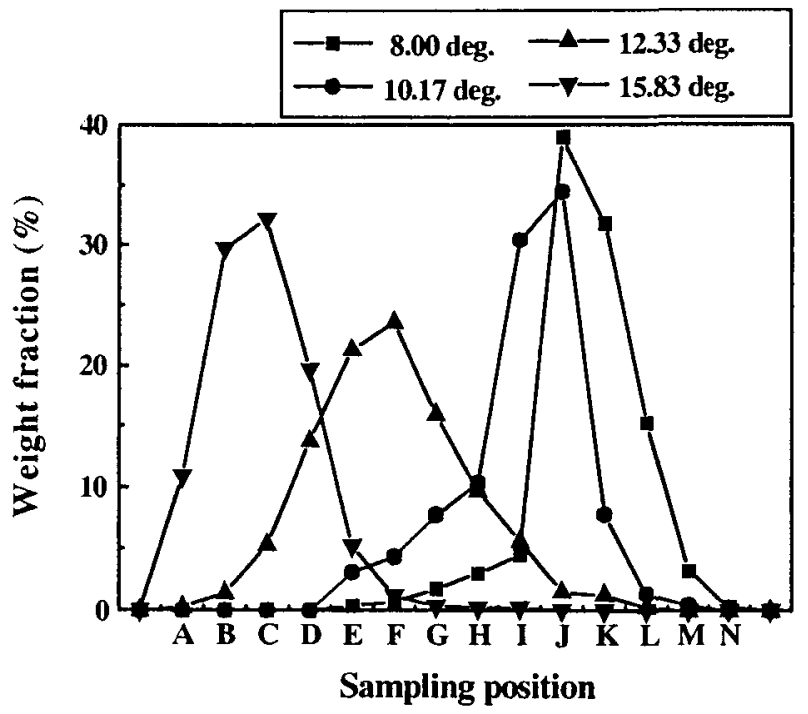

Fig.7 Effect of the inclination angle on the weight fraction collected in each position.

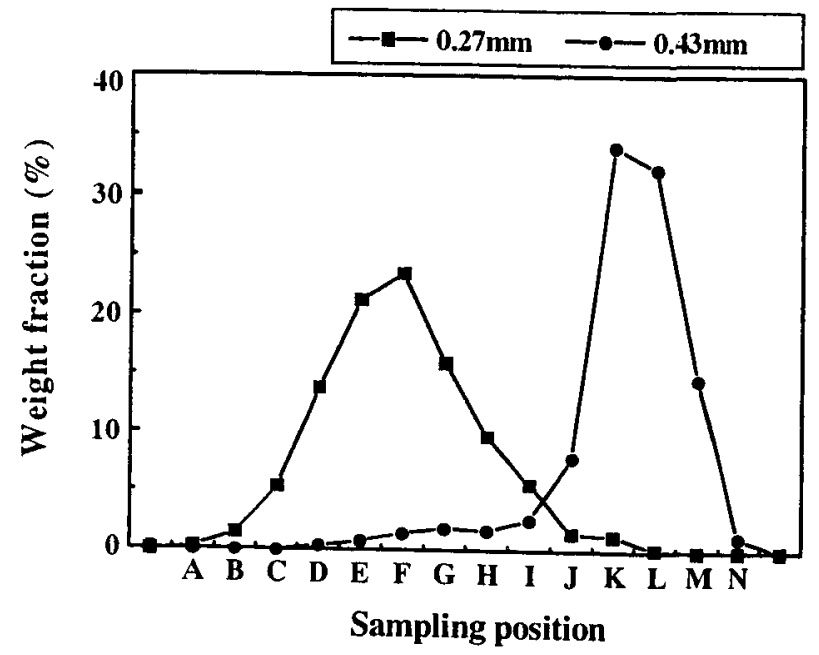

Fig.8 Effect of the amplitude of vibration on the weight fraction collected in each position.
収割合の変化から, 実験結果と同様な範囲に粉末粒子は回収 されていることがわかる.

4.3 分級する粉末や操作条件の形状分級に及ぼす影響

本研究では，操作条件や粉末の種類を変化させて，形状分 級への影響を調査検討した，形状分級の評価には，粉末粒子 の傾斜振動板上での転動挙動を反映する回収位置におけるの 回収割合を探用して検討した。

操作条件として，傾斜角，片振幅，周波数の形状分級に及 ぼす影響をFig.7,8および9にそれそれれ示す.使用粉末は, 125

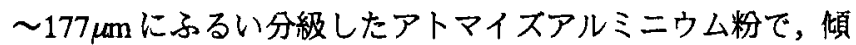
斜角 $12.33^{\circ}$ ，片振幅 $0.27 \mathrm{~mm}$, 周波数 $40 \mathrm{~Hz}$ を基準操作条件と して，影響を調查する操作条件のみを変化させて形状分級し た. Fig.7に示す傾斜角の影響では，傾斜角が大きくなるに 従って, 回収割合のピーク位置がより近い位置に移行する傾 向か認められる.片振幅の影響を示すFig.8において，振幅を 1.6倍に大きくすると, 回収割合のピークの位置がより遠い位 置に移行することがわかる.また，Fig.9に示す周波数の影響 については，明確な傾向が認められていない。

次に粉末の粒度の影響を Fig.10に示す. 53〜 75, 88〜125, 125〜177 $\mu \mathrm{m}$ にふるい分級した3種類のアトマイスアルミニウ 么粉を用いた。操作条件は, 頃斜角 $12.33^{\circ}$, 片振幅 $0.27 \mathrm{~mm}$, 周波数 $40 \mathrm{~Hz}$ とした. 粒度が小さくなるほど回収割合のピーク 位置はより遠くに移行している.これは，粉末粒子が小さい ほど振動による横方向への輸送が促進されることを意味して いる.

粉末の種類 (粒子密度) の違いによる影響を Fig.11に示す. 使用した粉末は,アトマイズアルミニウム粉, アトマイズ鉄

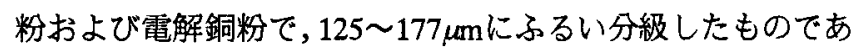
る. 操作条件は, 傾斜角 $12.33^{\circ}$, 片振幅 $0.27 \mathrm{~mm}$, 周波数 $40 \mathrm{~Hz}$ とした. 粉末の粒度と同様に粒子密度の小さい粉末ほど回収 割合のピーク位置はより遠くに移行することを想定していた が, 鉄と銅の間ではそれに反する結果となっている.これは,

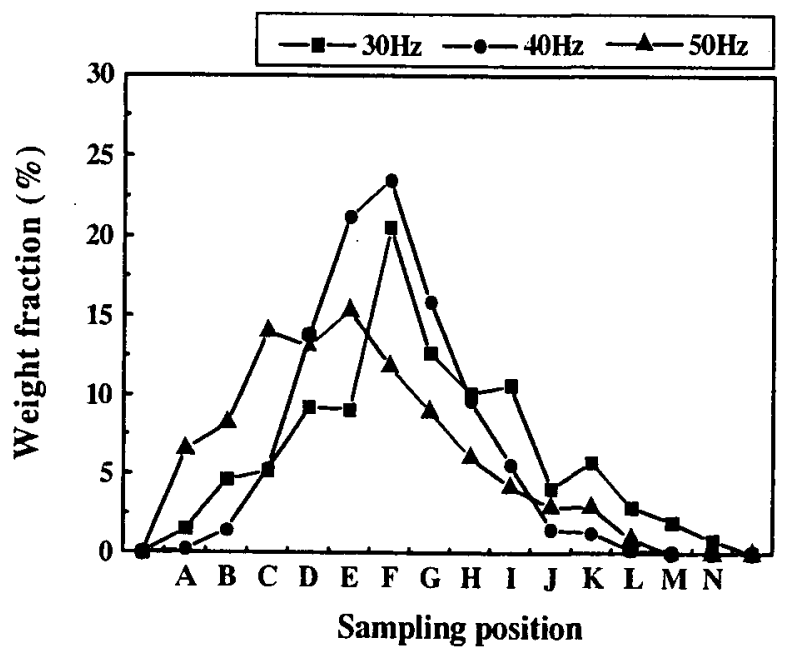

Fig.9 Effect of the frequency of vibration on the weight fraction collected in each position. 
図中に示すように，使用した銅粉末はその平均円形度が他の 粉末に比べて際立つて低く，複雑形状の粒子をより多く含む ために，粒子密度が鉄粉末よりも大きいにもかかわらず遠く まで輸送された粒子が多く存在したためと考えられる。

\section{5 粉末特性に及ぼす分級の効果}

本研究で実施した粒度分級および形状分級を用いて，粉末 特性に及ぼす粉末の粒度や形状の影響を調査した。市販のア トマイズアルミニウム粉(No.1)，それをふるいによって 88〜 125 および 125〜 177 $\mu \mathrm{m}$ に粒度分級した 2 種類の粉末(No.2,3), さらに125〜177 $\mu \mathrm{m}$ の粒度分級粉末を3種類に形状分級した粉 末(No.4,5,6)を調查対象粉末とした.これらの粉末における形 態の特性値を Table 1 に示す. 粉末特性としては，安息角，流

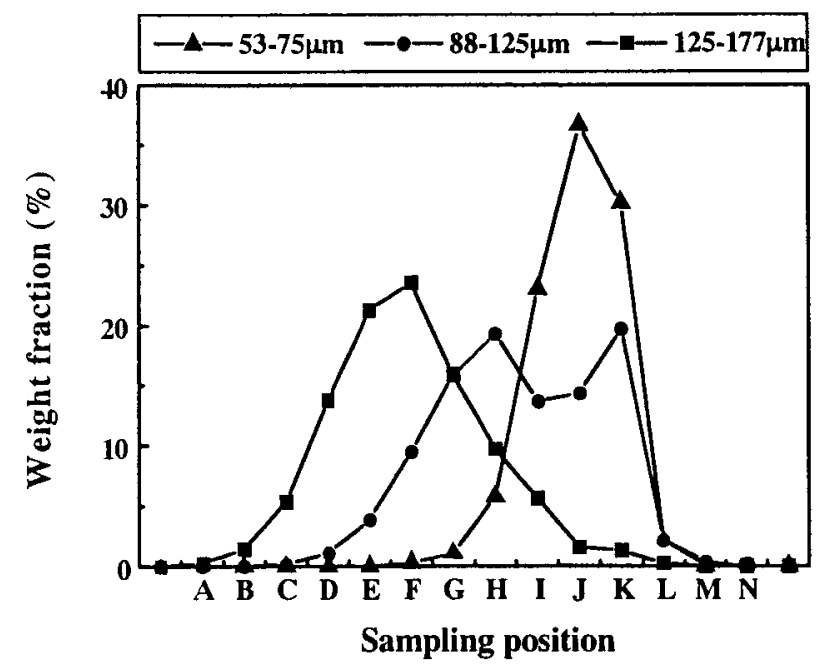

Fig.10 Effect of the particle size of powder on the weight fraction collected in each position.

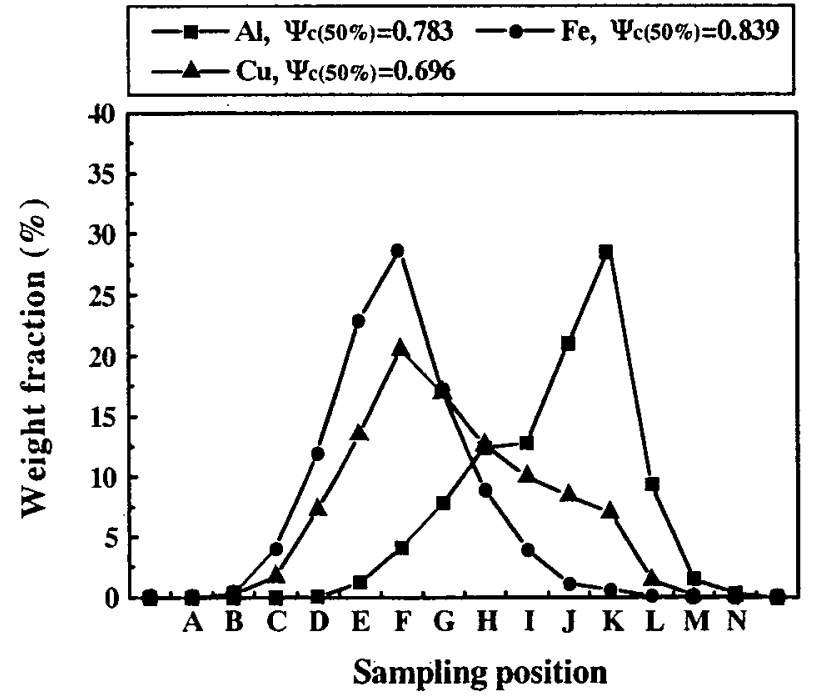

Fig.11 Effect of the difference in powder material on the weight fraction collected in each position.
動度，充填密度および圧粉挙動》の測定を実施した。それらの 結果をまとめて Fig.12に示す。

Fig.12(a)は，安息角の結果で，粒度分級による効果は少な いが，形状分級による効果は大きく，粉末粒子の形状が複雑 になるに従って安息角が大幅に增大することを表している. Fig.12(b)は，流動度の結果で，安息角と同様な傾向を持って いる.Fig.12(c)は，充填密度の結果で，粒度分級による効果 に比へて形状分級による効果は大きく，粉末粒子の形状が複 雑になるに従って充填密度が大幅に減少する結果となってい る.これは，粉末粒子の形状が複雑なほど粉末は詰りにくく なることを如実に表している. Fig.12(d)は，圧粉挙動の測定 結果で, 50MPaにおける相対密度によって圧粉初期における 王縮性を表現したものである。粒度範囲の広い市販の粉末 (No.1)では，最も高い纴縮性を示すが，粒度分級することで 圧縮性は低下し，複雑形状に形状分級することで圧縮性はさ らに低下することがわかる。これは，圧粉初期における粉末 粒子の再配列のしやすさと関連性が深いと考えられる。

\section{6 結 言}

本研究は，粉末治金用粉体に適応可能な形状分級技術の開 発と評価について検討し，以下の知見を得た。

(1) 傾斜振動板による形状分級では,同一の操作条件において 粒度や密度の違いによって分級は影響を受けるが,粒度分 級後の粉末では,形状分級の効果が十分に現れることが明 らかとなった。

(2) 棈円体粒子を傾斜振動板上で転動させる計算機シミュレー ションでは,傾斜振動板上における粒子挙動を表現するこ とができ，実際と同傾向の分級結果が得られた。

(3) 形状分級した粉末の安息角, 流動度, 充填密度および圧粉 挙動の測定を行った結果,形状分級の効果が明確に現れた. この技術は，製造プロセスの安定制御，製品の寸法精度の 向上，そして製品の高機能化のための高度な粉末調製に道を 開くものである。

\section{謝辞}

本研究は，粉体粉末治金協会萌芽的研究助成を受けて実施 したことをここに記し，謝意を表します．実験と計測で協力 を頂いた本学大学院修了生 中村佳道氏(現トピー工業株式会

Table 1 Morphological characteristics statistically determined of the samples.

\begin{tabular}{|c|c|c|}
\hline Sample & $D_{p(50 \%), \mu \mathrm{m}}$ & $\Psi \in(50 \%)$ \\
\hline No.1 & 126.8 & 0.795 \\
\hline No.2 & 153.1 & 0.743 \\
\hline No.3 & 196.4 & 0.781 \\
\hline No.4 & 178.7 & 0.901 \\
\hline No.5 & 182.3 & 0.817 \\
\hline No.6 & 185.1 & 0.677 \\
\hline
\end{tabular}


(a)
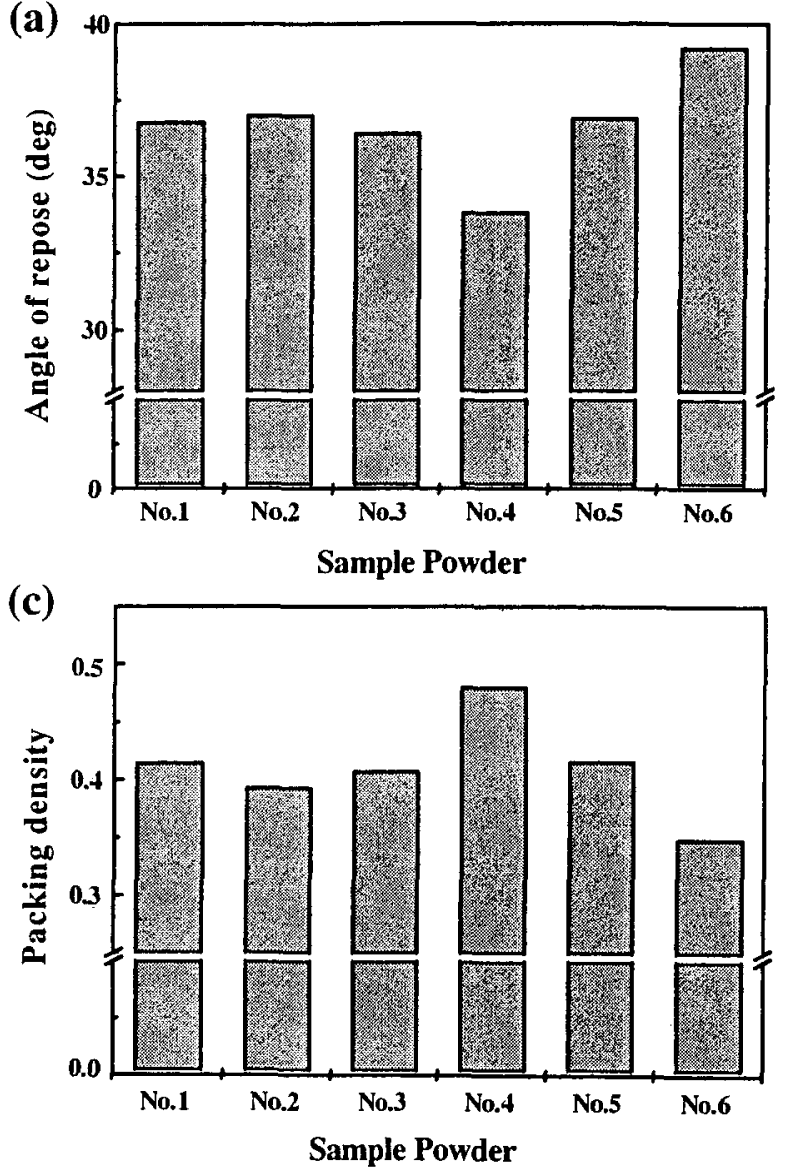
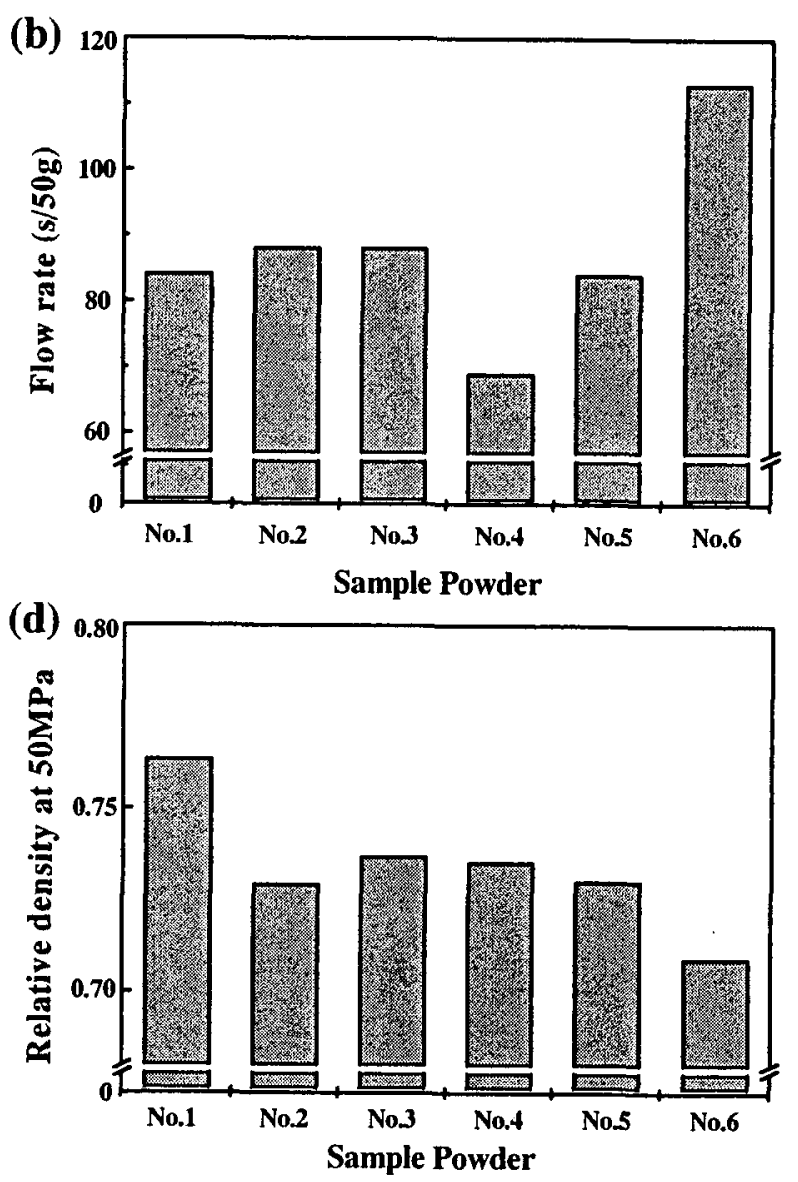

Fig.12 Measuring results of powder properties; (a) the angle of repose, (b) the flow rate, (c) the packing density and (d) the relative density at $50 \mathrm{MPa}$ compaction.

社)と, 本研究に粉末試料の提供を賜った福田金属箔粉工業株 式会社，東洋アルミニウム株式会社および株式会社神戸製鋼 所に感謝いたします.

\section{文献}

1) 古屋仲茂樹, 遠藤茂寿, 岩田博行: "形状分級技術を利用し たプリント基板廃材のリサイクリング",粉体工学会誌, 32 (1995)385-391.
2) T.Itoh and Y.Wanibe: "Particle Shape Distribution and Particle Size-Shape Dispersion Diagram", Powder Metallurgy, 34 (1991)126-134.

3) Y.Wanibe and T.Itoh: New Quantitative Approach to Powder Technology, John Wiley\&Sons, (1998)63-80.

4) T.Itoh and Y.Wanibe: "Relationship between Compacting Behaviors and Morphological Characteristics for Metallic Powders", 粉体および粉末冶金, 46(1999)16-21. 